\title{
Efektivitas Model Pembelajaran Treffinger dengan Pendekatan Saintifik terhadap Kemampuan Berpikir Tingkat Tinggi Siswa Kelas VIII SMP
}

\author{
Awi Dassa ${ }^{1, a)}$, Dinar $^{1, b)}$, dan Reni ${ }^{1, c)}$ \\ ${ }^{1}$ Jurusan Matematika, Fakultas MIPA, Universitas Negeri Makassar \\ a)awidassa@gmail.com \\ ${ }^{b)}$ m.dinar@unm.ac.id \\ c) ramadhanireni12@yahoo.co.id
}

\begin{abstract}
Abstrak. Penelitian ini bertujuan untuk mengetahui efektivitas model pembelajaran treffinger dengan pendekatan saintifik terhadap kemampuan berpikir tingkat tinggi siswa kelas VIII SMP mengacu pada efektivitas pembelajaran yaitu kemampuan berpikir tingkat tinggi, aktivitas, dan respon siswa. Penelitian ini merupakan penelitian pra-eksperimen dengan pendekatan kuantitatif dengan teknik pengambilan sampel yaitu cluster random sampling. Teknik analisis data yang digunakan adalah teknik analisis deskriptif dan inferensial. Hasil analisis deskriptif menunjukkan: (1) rata-rata hasil pretest siswa yaitu 31,10 (kategori kurang), rata-rata hasil posttest siswa yaitu 54,22 (kategori cukup baik) (2) hasil posttest menunjukkan ketuntasan klasikal tercapai yakni sebesar 100\% (21 siswa) mencapai ketuntasan individu, (3) rata-rata gain ternormalisasi sebesar 0,33 (kategori sedang), (4) rata-rata aktivitas siswa sebesar 3,67 (kategori sangat baik), (5) rata-rata presentase siswa yang memberi respon positif sebanyak 92,06\%. Hasil analisis inferensial menunjukkan: (1) nilai rata-rata kemampuan berpikir tingkat tinggi siswa yang diajar dengan model pembelajaran treffinger dengan pendekatan saintifik lebih besar dari 40 (kategori cukup baik), (2) nilai rata-rata gain ternormalisasi lebih besar dari 0,3 (kategori sedang), (3) terdapat peningkatan yang signifikan hasil belajar pada kemampuan berpikir tingkat tinggi siswa sebelum dan setelah penerapan model pembelajaran treffinger dengan pendekatan saintifik. Dari hasil penelitian ini dapat disimpulkan bahwa pembelajaran dengan penerapan model pembelajaran treffinger dengan pendekatan saintifik efektif diterapkan pada siswa kelas VIII SMP.
\end{abstract}

Kata Kunci: Efektivitas, Model pembelajaran treffinger, Pendekatan saintifik, Kemampuan berpikirc tingkat tinggi, Statistika

\begin{abstract}
This research aims to determine effectiveness of treffinger learning model with scientific approach to student's higher order thinking skills of grade VIII SMP by referring to effectiveness of learning, namely students' higher order thinking skills, student activities, and student responses. This research is pre-experimental study with quantitative approach and sampling technique used is cluster random sampling. Data analysis technique used is descriptive and inferential analysis techniques. Results of descriptive analysis showed: (1) average results of students' pretest was 31.10 (bad category), average student posttest result was 54.22 (good enough category) (2) the posttest results showed that classical completeness was reached at 100\% (21 students) achieved individual completeness, (3) average normalized gain was 0.33 (medium category), (4) average student activity was 3.67 (very good category), (5) average percentage of students who gave positive response of $92.06 \%$. Inferential analysis results show: (1) average value of higher order thinking skills of students taught with treffinger learning models with scientific approach greater than 40 (good enough category), (2) average normalized gain value is greater than 0,3 (medium category), (3) there is a significant increase in learning outcomes on students' higher order thinking skills before and after application of treffinger learning model with scientific
\end{abstract}


approach. From the results of this study it can be concluded that learning by applying the Treffinger learning model with scientific approach is effectively applied to students of grade VIII SMP.

Keywords: Effectiveness, Treffinger learning model, Scientific approach, Higher Order Thinking Skills, Statistics

\section{PENDAHULUAN}

Model pembelajaran merupakan pola yang digunakan guru sebagai pedoman dalam merencanakan serta melaksanakan pembelajaran di dalam kelas. Guru perlu memilih model pembelajaran yang sesuai. Model pembelajaran yang dipilih diharapkan dapat menciptakan suasana yang mendorong siswa untuk melaksanakan kegiatan di kelas dengan terlibat aktif dalam pembelajaran.

Saat ini pemerintah tengah menerapkan Kurikulum 2013 guna meningkatkan mutu pendidikan termasuk dalam pembelajaran matematika. Proses pembelajaran Kurikulum 2013 pada prinsipnya menekankan pada keaktifan siswa untuk menemukan konsep pelajaran dengan guru sebagai fasilitator. Adanya Kurikulum 2013 dapat meningkatkan pemahaman guru terhadap pembelajaran untuk siswa terkhusus model pembelajaran yang digunakan.

Sebagaimana tercantum dalam kurikulum Matematika Sekolah bahwa tujuan diberikannya matematika adalah agar siswa mampu menghadapi perubahan keadaan di dunia yang selalu berkembang, melalui latihan bertindak atas dasar pemikiran secara kritis dan kreatif. Sehingga, dapat menumbuhkan keaktifan siswa dalam pembelajaran. Untuk mencapai tujuan tersebut maka perlu dikembangkan materi serta proses pembelajaran yang sesuai.

Salah satu model pembelajaran yang dapat membantu siswa untuk berpikir kritis dan kreatif dalam memecahkan masalah adalah model pembelajaran treffinger. Selain itu, dapat membantu siswa dalam menguasai konsep materi dan menunjukkan potensi kemampuan yang dimilikinya termasuk kemampuan kreativitas dan kemampuan pemecahan masalah. Dengan kreativitas yang dimiliki, siswa mampu menggali potensi dalam berdaya cipta, menemukan gagasan serta pemecahan masalah melibatkan proses berpikir.

Penelitian ini ditunjang dengan beberapa penelitian terkait yang dilakukan sebelumnya seperti yang dilakukan oleh Sari (2014) yang meneliti tentang penerapan model treffinger pada pembelajaran matematika dalam mengembangkan kemampuan kreatif matematika. Hasilnya menunjukkan bahwa kemampuan kreativitas siswa dalam pemecahan masalah matematika yang diajarkan dengan model treffinger lebih baik daripada yang diajar dengan model pembelajaran biasa. Alifia (2018) meneliti tentang kemampuan creative and critical thinking melalui model pembelajaran treffinger. Hasilnya menunjukkan bahwa kemampuan creative and critical thinking siswa menggunakan model pembelajaran treffinger lebih baik daripada siswa yang diajar menggunakan model pembelajaran konvensional.

Pendekatan pembelajaran adalah konsep dasar yang mewadahi, menginspirasi, menguatkan, dan melatari pemikiran tentang bagaimana metode pembelajaran diterapkan berdasarkan teori tertentu. Selain itu, pendekatan merupakan cara mengelola kegiatan pembelajaran agar siswa dapat aktif melakukan tugas belajar dan dapat memperoleh hasil belajar secara optimal. Maka, guru perlu memilih pendekatan pembelajaran yang sesuai dengan model pembelajaran yang akan digunakan.

Proses pembelajaran Kurikulum 2013 untuk semua jenjang dilaksanakan dengan menggunakan pendekatan saintifik yaitu pendekatan pembelajaran yang berpusat pada peserta didik. Pendekatan saintifik berarti konsep dasar yang menginspirasi atau melatarbelakangi perumusan metode mengajar dengan menerapkan karakteristik yang ilmiah. Salah satu kriteria pendekatan saintifik (Permendikbud, 2013) yaitu mendorong dan menginspirasi siswa berpikir secara kritis, kreatif, dan tepat dalam mengidentifikasi, memahami, memecahkan masalah, dan mengaplikasikan materi pembelajaran. 
Penelitian terkait yang dilakukan oleh Widiani (2016) yang meneliti tentang penerapan pendekatan saintifik dalam pembelajaran matematika dan pengaruhnya terhadap kemampuan komunikasi matematis dan berpikir kreatif siswa. Hasilnya menunjukkan bahwa siswa mengalami peningkatan kemampuan berpikir kreatif. Asmi (2015) yang meneliti tentang pengaruh pendekatan scientific terhadap kemampuan berpikir kritis siswa dalam pembelajaran matematika. Hasilnya menunjukkan bahwa kemampuan berpikir kritis matematik siswa yang signifikan pada kelas yang pembelajarannya menggunakan pendekatan scientific.

Kurikulum 2013 menekankan pada kecerdasan tingkat tinggi yang dibingkai oleh sikap ketuhanan dan nilai-nilai sosial yang terintegrasi dalam proses pembelajaran. Kemampuan berpikir tingkat tinggi menjadi landasan implementasi Kurikulum 2013. Kurikulum 2013 juga menuntut pemberian masalah matematika untuk mengembangkan kemampuan kognitif yang mendorong kemampuan berpikir siswa.

Kemampuan berpikir tingkat tinggi disebut sebagai gabungan dari berpikir kritis dan kreatif. Kemampuan berpikir kritis merupakan kompetensi kognitif tertinggi yang perlu dikuasai siswa dalam pembelajaran, dipandang sebagai kemampuan berpikir siswa untuk membanding dua atau lebih informasi. Kemampuan berpikir kreatif berkenan dengan kemampuan menghasilkan atau mengembangkan sesuatu yang baru, tidak biasa dan berbeda dari ide-ide yang dihasilkan kebanyakan orang. Guru perlu melibatkan siswa secara aktif dalam proses pembelajaran dan memberikan soal yang melatih proses berpikir kritis dan kreatif siswa, agar kemampuan berpikir tingkat tinggi siswa berkembang secara optimal.

Beberapa penelitian telah mengkaji tentang kemampuan berpikir tingkat tinggi Siswa (Wicasari, 2016; Kurniati, 2016; Hugo, 2017). Penelitian tersebut dilakukan dengan mengembangkan instrumen tes dan memberikan soal matematika yang mengukur kemampuan berpikir tingkat tinggi siswa. Hasilnya menunjukkan bahwa soal yang diberikan dapat mengembangkan kemampuan berpikir tingkat tinggi siswa.

Pada penelitian ini, model pembelajaran treffinger dikombinasikan dengan pendekatan saintifik, Model dan pendekatan ini diharapkan dapat mendorong siswa terlibat aktif dalam proses pembelajaran matematika dan meningkatkan kemampuan berpikir kritis dan kreatif siswa. Adapun tujuan penelitian ini adalah untuk mengetahui efektivitas model pembelajaran treffinger dengan pendekatan saintifik terhadap kemampuan berpikir tingkat tinggi siswa.

\section{KAJIAN PUSTAKA}

\section{Model Pembelajaran Treffinger}

Model pembelajaran treffinger merupakan model pembelajaran yang mengajak siswa berpikir kreatif dalam menghadapi masalah (Huda, 2013). Siswa diberi keleluasaan untuk berkreativitas menyelesaikan permasalahan secara mandiri. Menurut Treffinger (1980), model treffinger adalah model yang berupaya untuk mengajak siswa berpikir kreatif dalam memecahkan masalah dengan memperhatikan fakta-fakta penting yang ada di lingkungan sekitar lalu memunculkan berbagai gagasan dan memilih solusi yang tepat untuk diimplementasikan secara nyata. Pada prosesnya model ini memperlihatkan keterkaitan antara berpikir kreatif dan kritis. Berpikir kreatif terjadi ketika ingin memunculkan banyak ide sedangkan ketika mengevaluasi berarti melatih berpikir kritis.

Menurut Munandar (2009) bahwa model pembelajaran treffinger terdiri dari langkah-langkah berikut:

1. Tahap I - basic tools

Adapun kegiatan pembelajaran pada tahap I dalam penelitian ini, yaitu (1) guru memberikan suatu masalah terbuka dengan jawaban lebih dari satu penyelesaian, (2) 
guru membimbing siswa melakukan diskusi untuk menyampaikan gagasan atau idenya sekaligus memberikan penilaian pada masing-masing kelompok.

2. Tahap II - Practice with process

Adapun kegiatan pembelajaran pada tahap II dalam penelitian ini, yaitu (1) guru membimbing dan mengarahkan siswa untuk berdiskusi dengan memberikan contoh analog, (2) guru meminta siswa membuat contoh dalam kehidupan sehari-hari.

3. Tahap III - Working with real problem

Working with real problem, yaitu menerapkan keterampilan yang dipelajari pada dua tahap pertama terhadap tantangan pada dunia nyata. Disini siswa menggunakan kemampuannya dengan cara-cara yang bermakna bagi kehidupannya. Siswa tidak hanya belajar keterampilan berpikir kreatif, tetapi juga bagaimana menggunakan informasi ini dalam kehidupan mereka.

Beberapa penelitian telah mengkaji terkait model pembelajaran treffinger. Sari (2014) meneliti tentang penerapan model treffinger pada pembelajaran matematika dalam mengembangkan kemampuan kreatif matematika siswa. Dari hasil penelitian diperoleh skor rata-rata kemampuan berpikir kreatif siswa yang mengikuti pembelajaran dengan model treffinger yaitu 76,91, dengan skor tertinggi 99 dan skor terendah 50. Sedangkan skor rata-rata kemampuan berpikir kreatif siswa yang mengikuti pembelajaran biasa yaitu 62,37, dengan skor tertinggi 88 dan skor terendah 34. Dari penelitian tersebut, menunjukkan bahwa penerapan model treffinger lebih baik dari pada model pembelajaran biasa dalam mengembangkan kemampuan kreatif matematika siswa.

Penelitian terkait juga dilakukan oleh Alifia (2018) yang meneliti tentang kemampuan creative and critical thinking melalui model pembelajaran treffinger. Hasil penelitian menunjukkan bahwa terdapat perbedaan yang signifikan antara kemampuan creative and critical thinking peserta didik kelas eksperimen dan kelas kontrol. Selain itu, kemampuan creative and critical thinking peserta didik kelas eksperimen lebih baik daripada kelas kontrol dan peserta didik kelas eksperimen lebih dominan memenuhi indikator kemampuan creative and critical thinking.

\section{Pendekatan Saintifik}

Pendekatan saintifik berarti konsep dasar yang menginspirasi atau melatarbelakangi perumusan metode mengajar dengan menerapkan karakteristik yang ilmiah. Pendekatan pembelajaran ilmiah merupakan bagian dari pendekatan pedagogis pada pelaksanaan pembelajaran dalam kelas yang melandasi penerapan metode ilmiah (Musfiqon, 2015).

Proses pembelajaran yang mengacu pada pendekatan saintifik menurut Kemdikbud (2017) meliputi lima langkah, yaitu: mengamati, menanya, mengumpulkan data, mengasosiasi, dan mengkomunikasikan. Pendekatan saintifik dimaksudkan untuk memberikan pemahaman kepada peserta didik dalam memahami berbagai materi menggunakan pendekatan ilmiah. Selain itu, dapat mendorong siswa mencari tahu dan mendapatkan dari berbagai sumber melalui kegiatan ilmiah.

Penelitian terkait yang dilakukan oleh Widiani (2016) yang meneliti tentang penerapan pendekatan saintifik dalam pembelajaran matematika dan pengaruhnya terhadap kemampuan komunikasi matematis dan berpikir kreatif siswa. Hasil penelitian diperoleh setelah dilakukan pembelajaran matematika menggunakan pendekatan saintifik dan pengaruhnya terhadap kemampuan komunikasi matematis dan berpikir kreatif mengalami peningkatan yaitu rerata sebesar $82,45 \%$ dan $84,48 \%$. Maka, diperoleh kesimpulan bahwa siswa mengalami peningkatan kemampuan berpikir kreatif.

Penelitian terkait lainnya dilakukan oleh Asmi (2015) meneliti tentang pengaruh pendekatan scientific terhadap kemampuan berpikir kritis siswa dalam pembelajaran matematika. Hasil penelitian yang diperoleh yaitu rerata normalized gain sebesar 0,40. Kemampuan berpikir kritis siswa memiliki klasifikasi sedang dengan nilai gain terbesar sebesar 0,71 dan nilai gain terkecil 
sebesar 0,06. Hal ini menunjukkan bahwa kemampuan berpikir kritis matematik siswa yang signifikan pada kelas yang pembelajarannya menggunakan pendekatan scientific,

\section{Kemampuan Berpikir Tingkat Tinggi}

Berpikir tingkat tinggi adalah berpikir level yang lebih tinggi dari pada sekedar mengingat fakta atau menceritakan kembali sesuatu yang didengar kepada orang lain (Thomas \& Thorne, 2009). Berpikir tingkat tinggi menuntut seseorang untuk melakukan sesuatu terhadap fakta, yaitu memahaminya, menyimpulkannya, menghubungkannya dengan fakta lain, memanipulasi, dan menerapkannya dalam mencari solusi dari masalah. Kemampuan berpikir tingkat tinggi menuntut adanya proses berpikir yang lebih kompleks dalam menghadapi situasi atau memecahkan suatu masalah.

Kemampuan berpikir terdapat pada ranah kognitif Taksonomi Bloom terdiri dari enam level: remembering (mengingat), understanding (memahami), applying (menerapkan), analyzing (menganalisis), evaluating (menilai) dan creating (mencipta) (Kreathwohl, 2002). Proses kognitif yang dikategorikan sebagai kemampuan berpikir tingkat tinggi yaitu analyzing (menganalisis), evaluating (menilai) dan creating (mencipta). Kemampuan analisis yang merupakan kemampuan berpikir dalam menspesifikasi aspek dari sebuah konteks tertentu. Kemampuan evaluasi merupakan kemampuan berpikir dalam mengambil keputusan berdasarkan fakta. Kemampuan mengkreasi merupakan kemampuan berpikir dalam membangun gagasan/ide.

Beberapa penelitian telah mengkaji tentang kemampuan berpikir tingkat tinggi siswa (Wicasari, 2016; Kurniati, 2016; Hugo, 2017). Wicasari (2016) meneliti tentang analisis kemampuan berpikir siswa dalam menyelesaikan permasalahan matematika yang berorientasi pada kemampuan berpikir tingkat tinggi. Hasilnya menunjukkan bahwa soal yang diberikan dapat mengembangkan kemampuan berpikir tingkat tinggi siswa. Kurniati (2016) meneliti tentang kemampuan berpikir tingkat tinggi siswa SMP dalam menyelesaikan soal berstandar PISA. Hasil penelitian menunjukkan bahwa siswa mampu melakukan kemampuan logika dan penalaran, analisis, evaluasi, serta kreasi dengan baik dalam menyelesaikan beberapa soal. Serta, Hugo (2017) meneliti tentang pengembangan instrumen tes untuk mengukur kemampuan berpikir tingkat tinggi siswa. Instrumen tes untuk mengukur kemampuan berpikir tingkat tinggi siswa memenuhi indikator ketepatan. Selain itu, kemampuan berpikir tingkat tinggi siswa memenuhi kriteria cukup. Dari ketiga penelitian tersebut, dapat disimpulkan bahwa dari hasil penyelesaian soal, siswa mampu mencapai kemampuan berpikir tingkat tinggi.

\section{METODE PENELITIAN}

Jenis penelitian yang digunakan adalah jenis penelitian pra-eksperimen. Desain penelitian dalam penelitian ini ditunjukkan pada Tabel 1 .

TABEL 1. Desain Penelitian One Group - Pretest Posttest Design

\begin{tabular}{ccc}
\hline Pretest & Variabel Terikat & Posttest \\
\hline $\mathrm{O} 1$ & $\mathrm{X}$ & $\mathrm{O} 2$ \\
\hline
\end{tabular}

Keterangan :

O1 : tes awal (pretest) sebelum perlakuan diberikan

O2 : tes akhir (posttest) setelah perlakuan diberikan

$\mathrm{X}$ : perlakuan terhadap kelompok eksperimen yaitu dengan menerapkan model pembelajaran treffinger dengan pendekatan saintifik 
Penelitian ini dilaksanakan di kelas VIII pada SMP Negeri di Kabupaten Sidrap. Sampel dalam penelitian ini terdiri dari 21 siswa. Ada dua jenis variabel dalam penelitian ini yaitu variabel bebas dan variabel terikat. Variabel bebas dalam penelitian ini adalah pembelajaran dengan menggunakan model pembelajaran treffinger dengan pendekatan saintifik. Sedangkan variabel terikatnya adalah kemampuan berpikir tingkat tinggi, aktivitas siswa, dan respon siswa.

Teknik pengumpulan data dilakukan dengan pemberian tes, pengisian angket, dan pengisian lembar observasi. Instrumen yang dikembangkan yaitu tes kemampuan berpikir tingkat tinggi, lembar observasi keterlaksanaan pembelajaran, lembar observasi aktivitas siswa, dan angket respon siswa. Instrumen telah divalidasi oleh dua ahli.

Analisis data yang digunakan pada penelitian ini yaitu analisis statistik deskriptif dan analisis statistik inferensial. Analisis statistik deskriptif digunakan untuk mendeskripsikan setiap variabel penelitian. Analisis statistik inferensial digunakan untuk menguji hipotesis penelitian Namun, sebelumnya dilakukan uji prasyarat yaitu uji normalitas. Uji normalitas yang digunakan yaitu uji Kolmogorov-smirnov.

Hipotesis dalam penelitian ini adalah rata-rata kemampuan berpikir tingkat tinggi siswa (posttest) setelah penerapan model pembelajaran treffinger dengan pendekatan saintifik lebih besar dari 40 (skor minimal 41). Peningkatan kemampuan berpikir tingkat tinggi siswa yaitu skor rata-rata posttest lebih tinggi daripada skor rata-rata pretest (rata-rata gain ternormalisasi melebihi 0,3). Dan proporsi siswa yang mencapai ketuntasan belajar dengan menggunakan model pembelajaran treffinger dengan pendekatan saintifik secara klasikal lebih besar dari $64 \%$ (65\% siswa mencapai skor minimal).

\section{HASIL DAN PEMBAHASAN}

Penelitian dilaksanakan dengan 6 pertemuan, 1 pertemuan pemberian pretest, 1 pertemuan pemberian posttest, dan 4 pertemuan pemberian pembelajaran dengan menggunakan model pembelajaran treffinger dengan pendekatan saintifik. Pretest merupakan tes awal yang diberikan sebelum pembelajaran dilaksanakan. Sedangkan, posttest merupakan tes akhir setelah pembelajaran dilaksanakan. Selain itu, selama proses pembelajaran berlangsung, dilakukan pengisian lembar observasi keterlaksanaan pembelajaran dan lembar observasi aktivitas siswa. Adapun, angket respon siswa diisi oleh siswa setelah pembelajaran dilaksanakan.

\section{Keterlaksanaan Model Pembelajaran Treffinger dengan Pendekatan Saintifik}

TABEL 2. Rekapitulasi Hasil Observasi Keterlaksanaan Pembelajaran

\begin{tabular}{cccccc}
\hline \multirow{2}{*}{ Pertemuan } & \multicolumn{3}{c}{ Kegiatan Pembelajaran } & \multirow{2}{*}{ Rata-rata } & \multirow{2}{*}{ Kategori } \\
\cline { 2 - 4 } & Pendahuluan & Inti & Penutup & & \\
\hline 1 & 3,8 & 3,7 & 3,25 & 3,58 & Terlaksana dengan baik \\
2 & 3,8 & 3,7 & 3,75 & 3,75 & Terlaksana dengan baik \\
3 & 3,8 & 3,9 & 4 & 3,9 & Terlaksana dengan baik \\
4 & 4 & 3,9 & 4 & 3,97 & Terlaksana dengan baik \\
\hline Rata-rata & 3,85 & 3,8 & 3,75 & 3,8 & Terlaksana dengan baik \\
\hline
\end{tabular}

Pada Tabel 2, secara kuantitatif menunjukkan bahwa untuk skor rata-rata semua pertemuan yaitu 3,8 dan berada pada interval $(3,5-4,0)$. Maka dapat disimpulkan secara keseluruhan observasi terhadap keterlaksanaan model pembelajaran treffinger dengan pendekatan saintifik dikatakan "terlaksana dengan baik".

Secara kualitatif, guru melaksanakan semua aspek dalam kegiatan pembelajaran. Selain itu, guru memperhatikan kesediaan siswa dalam melaksanakan perintah atau arahan dari guru dan siswa memberikan respon terhadap arahan tersebut. Akan tetapi, terkadang guru tidak memperhatikan dan tidak memberikan respon balik terhadap respon yang diberikan siswa. 


\section{Kemampuan Berpikir Tingkat Tinggi Siswa}

\section{Analisis Deskriptif}

Data yang diperoleh dalam penelitian ini adalah data tentang hasil belajar matematika siswa. Hasil belajar siswa berdasarkan pada kemampuan berpikir tingkat tinggi siswa yang diajarkan dengan penerapan model pembelajaran treffinger dengan pendekatan saintifik. Data dideskripsikan berdasarkan analisis data tes awal (pretest) dan tes akhir (posttest).

TABEL 3. Rekapitulasi Nilai Pretest Kemampuan Berpikir Tingkat Tinggi Siswa

\begin{tabular}{|c|c|}
\hline Statistik & Nilai \\
\hline Ukuran Sampel & 21 \\
\hline Mean & 31,10 \\
\hline Median & 25,00 \\
\hline Modus & 25,00 \\
\hline Standar Deviasi & 7,29 \\
\hline Varians & 53,20 \\
\hline Minimum & 25,00 \\
\hline Maksimum & 43,75 \\
\hline
\end{tabular}

Pada Tabel 3 menunjukkan bahwa skor rata-rata kemampuan berpikir tingkat tinggi siswa sebelum penerapan model pembelajaran treffinger dengan pendekatan saintifik adalah 31,10 dengan dari skor ideal 100. Skor rata-rata tersebut menunjukkan bahwa kemampuan berpikir tingkat tinggi yang dimiliki siswa kurang baik. Dengan kata lain, kemampuan berpikir yang dimiliki siswa merupakan kemampuan berpikir tingkat rendah. Skor yang dicapai siswa tersebar dari skor terendah 25 sampai dengan skor tertinggi 43,75 dengan rentang 18,75.

TABEL 4. Distribusi dan Perentase Nilai Pretest Kemampuan Berpikir Tingkat Tinggi Siswa

\begin{tabular}{cccc}
\hline Nilai siswa & Kategori & Frekuensi & Persentase (\%) \\
\hline $81-100$ & Sangat baik & 0 & 0 \\
$61-80$ & Baik & 0 & 0 \\
$41-60$ & Cukup Baik & 3 & 14,29 \\
$21-40$ & Kurang & 18 & 85,71 \\
$0-20$ & Sangat Kurang & 0 & 0 \\
\hline \multicolumn{2}{c}{ Jumlah } & 21 & 100 \\
\hline
\end{tabular}

Pada Tabel 4 menunjukkan bahwa ketuntasan klasikal tidak terpenuhi dengan hanya 14,29\% siswa mencapai ketuntasan individu yang memiliki kemampuan berpikir tingkat tinggi cukup baik. Sedangkan $85,71 \%$ siswa tidak mencapai ketuntasan individu dengan memiliki kemampuan berpikir tingkat tinggi kurang baik. Sehingga, skor rata-rata kemampuan berpikir tingkat tinggi siswa sebelum diajar dengan model pembelajaran treffinger dengan pendekatan saintifik pada kategori "kurang".

TABEL 5. Rekapitulasi Nilai Posttest Kemampuan Berpikir Tingkat Tinggi Siswa

\begin{tabular}{lcc}
\hline & Statistik & Nilai \\
\hline Ukuran Sampel & 21 \\
Mean & 54,22 \\
Median & 52,08 \\
Modus & 52,08 \\
Standar Deviasi & 6,52 \\
Varians & 42,48 \\
Minimum & 41,67 \\
Maksimum & 63,54 \\
\hline
\end{tabular}

Pada Tabel 5 menunjukkan bahwa skor rata-rata kemampuan berpikir tingkat tinggi siswa setelah penerapan model pembelajaran treffinger dengan pendekatan saintifik adalah 54,22 
dengan dari skor ideal 100. Skor rata-rata tersebut menunjukkan bahwa siswa telah mencapai kemampuan berpikir tingkat tinggi. Hal ini juga dapat dilihat baik dari skor tertinggi 63,54 maupun skor terendah 41,67 mencapai kriteria kemampuan berpikir tingkat tinggi dengan skor lebih dari 40.

TABEL 6. Distribusi dan Persentase Nilai Posttest Kemampuan Berpikir Tingkat Tinggi Siswa

\begin{tabular}{cccc}
\hline Nilai siswa & Kategori & Frekuensi & Persentase (\%) \\
\hline $81-100$ & Sangat baik & 0 & 0 \\
$61-80$ & Baik & 5 & 23,81 \\
$41-60$ & Cukup Baik & 16 & 76,19 \\
$21-40$ & Kurang & 0 & 0 \\
$0-20$ & Sangat Kurang & 0 & 0 \\
\hline \multicolumn{2}{c}{ Jumlah } & 21 & 100
\end{tabular}

Pada Tabel 6 diatas menunjukkan bahwa ketuntasan klasikal terpenuhi dengan $100 \%$ siswa mencapai ketuntasan individu. Terdapat $76,19 \%$ siswa memiliki kemampuan berpikir tingkat tinggi cukup baik dan $23,81 \%$ siswa memiliki kemampuan berpikir tingkat tinggi baik. Sehingga, skor rata-rata kemampuan berpikir tingkat tinggi siswa setelah diajar dengan model pembelajaran treffinger dengan pendekatan saintifik berada pada kategori "cukup baik".

TABEL 7. Rekapitulasi Peningkatan Kemampuan Berpikir Tingkat Tinggi Siswa

\begin{tabular}{|c|c|}
\hline Statistik & Nilai \\
\hline Ukuran Sampel & 21 \\
\hline Mean & 0,33 \\
\hline Median & 0,35 \\
\hline Modus & 0,36 \\
\hline Standar Deviasi & 0,08 \\
\hline Varians & 0,01 \\
\hline Minimum & 0,22 \\
\hline Maksimum & 0,49 \\
\hline
\end{tabular}

Pada Tabel 7 dapat dijelaskan bahwa dengan jumlah siswa 21 orang, kelas yang diajar melalui penerapan model pembelajaran treffinger dengan pendekatan saintifik mengalami rata-rata peningkatan sebesar 0,33. Rata-rata pretest 31,10 dan rata-rata posttest 54,22. Rata-rata peningkatan hasil belajar siswa menunjukkan bahwa terjadi peningkatan kemampuan berpikir siswa dari kemampuan berpikir tingkat rendah menjadi kemampuan berpikir tingkat tinggi yang diajar menggunakan model pembelsjaran treffinger dengan pendekatan saintifik.

TABEL 8. Klasifikasi gain ternormalisasi kemampuan berpikir tingkat tinggi siswa

\begin{tabular}{cccc}
\hline Koefisien Normalisasi Gain & Jumlah Siswa & Persentase & Klasifikasi \\
\hline $\mathrm{g}<0,3$ & 8 & $14,29 \%$ & Rendah \\
$0,3 \leq \mathrm{g}<0,7$ & 13 & $85,71 \%$ & Sedang \\
$\mathrm{g} \geq 0,7$ & 0 & $0 \%$ & Tinggi \\
\hline
\end{tabular}

Pada Tabel 8 , peningkatan kemampuan berpikir tingkat tinggi siswa yang diajar menggunakan model pembelajaran treffinger dengan pendekatan saintifik sebagian besar berada pada kategori sedang yaitu sebanyak $85,71 \%$ siswa. Hal ini menunjukkan siswa mengalami peningkatan hasil belajar dan kemampuan berpikir tingkat tinggi siswa berkembang. Sedangkan, 14,29\% siswa berada dalam kategori rendah. Hal ini terjadi karena peningkatan hasil belajar siswa dari skor pretest dan posttest rendah sehingga kemampuan berpikir tingkat tinggi siswa kurang berkembang.

Setelah penerapan model pembelajaran treffinger dengan pendekatan saintifik diperoleh skor rata-rata kemampuan berpikir tingkat tinggi siswa minimal skor 41 sebanyak 76,19\% siswa. Sehingga memenuhi ketuntasan secara klasikal lebih dari $65 \%$ serta gain ternormalisasi dengan skor 0,33 pada kategori sedang. Hal ini menunjukkan terjadinya peningkatan kemampuan 
berpikir tingkat tinggi siswa yang signifikan terhadap penerapan model pembelajaran treffinger dengan pendekatan saintifik.

\section{Analisis Inferensial}

Pada analisis inferensial, berdasarkan uji normalitas untuk hasil posttest kemampuan berpikir tingkat tinggi siswa diperoleh $p$-value $>\alpha$ yaitu $0,715>0,05$. Peningkatan (nilai gain) kemampuan berpikir tingkat tinggi siswa diperoleh $p$-value $>\alpha$ yaitu $0,829>0,05$. Hal ini menunjukkan bahwa data hasil posttest kemampuan berpikir tingkat tinggi siswa dan data peningkatan (nilai gain) kemampuan berpikir tingkat tinggi siswa berasal dari populasi yang berdistribusi normal.

Selanjutnya pengujian hipotesis untuk nilai posttest menunjukkan bahwa $t=37,84$ dengan derajat kebebasan $=20$ dan $p$-value $=0,000$. Karena $p<\alpha$ maka $\mathrm{H}_{\mathrm{o}}$ ditolak atau $\mathrm{H}_{1}$ diterima. Ini berarti bahwa untuk nilai posttest kemampuan berpikir tingkat tinggi menunjukkan bahwa nilai rata-rata posttest lebih dari 40 (skor minimal 41). Proporsi siswa mencapai kriteria pencapaian lebih dari 64\% (minimal 65\%). Serta peningkatan kemampuan berpikir tingkat tinggi menunjukkan nilai rata-rata gain ternormalisasi lebih dari 0,3 (kategori sedang).

\section{Aktivitas Siswa}

TABEL 9. Rekapitulasi Hasil Observasi Aktivitas Siswa

\begin{tabular}{|c|c|c|c|c|c|c|}
\hline \multirow{2}{*}{$\begin{array}{l}\text { Aspek yang } \\
\text { diobservasi }\end{array}$} & \multicolumn{4}{|c|}{$\begin{array}{l}\text { Skor rata-rata aktivitas } \\
\text { siswa setiap pertemuan }\end{array}$} & \multirow[t]{2}{*}{ Rata-rata } & \multirow[t]{2}{*}{ Kategori } \\
\hline & I & II & III & IV & & \\
\hline 1 & 4 & 4 & 4 & 4 & 4 & Sangat baik \\
\hline 2 & 4 & 4 & 4 & 4 & 4 & Sangat baik \\
\hline 3 & 4 & 4 & 4 & 4 & 4 & Sangat baik \\
\hline 4 & 3 & 4 & 3 & 3 & 3,25 & Baik \\
\hline 5 & 3 & 3 & 3 & 3 & 3 & Baik \\
\hline 6 & 4 & 4 & 4 & 4 & 4 & Sangat baik \\
\hline 7 & 4 & 4 & 4 & 4 & 4 & Sangat baik \\
\hline 8 & 3 & 4 & 4 & 4 & 3,75 & Sangat baik \\
\hline 9 & 3 & 3 & 4 & 4 & 3,5 & Sangat baik \\
\hline 10 & 3 & 3 & 3 & 4 & 3,25 & Baik \\
\hline 11 & 3 & 4 & 4 & 4 & 3,75 & Sangat baik \\
\hline 12 & 3 & 4 & 4 & 4 & 3,75 & Sangat baik \\
\hline 13 & 4 & 4 & 4 & 4 & 4 & Sangat baik \\
\hline 14 & 3 & 3 & 3 & 3 & 3 & Baik \\
\hline 15 & 4 & 3 & 4 & 4 & 3,75 & Sangat baik \\
\hline Rata-rata & 3,47 & 3,67 & 3,73 & 3,8 & 3,67 & Sangat baik \\
\hline
\end{tabular}

Hasil observasi aktivitas siswa menunjukkan bahwa aspek yang diamati memenuhi kriteria efektif dimana skor rata-rata untuk semua pertemuan yaitu 3,67. Dengan skor berada pada interval $(3,5-4,0)$ pada kategori "sangat baik". Hal ini menunjukkan bahwa kriteria keefektifan pembelajaran untuk aktivitas siswa terpenuhi.

Selanjutnya berdasarkan analisis kualitatif, masih ada siswa yang kurang aktif dan kurang termotivasi dalam kegiatan pembelajaran sehingga ragu menyampaikan pendapatnya. Namun sebagian besar siswa menunjukkan keaktifan, motivasi, perhatian, kesungguhan, dan keterampilan dengan penerapan model pembelajaran treffinger dengan pendekatan saintifik. Hal ini dapat berpengaruh terhadap ketuntasan belajar siswa. Sehingga, siswa pun mengalami peningkatan kemampuan berpikir tingkat tinggi. 


\section{Respon Siswa}

TABEL 10. Data Angket Respon Siswa

\begin{tabular}{ccccc}
\hline \multirow{2}{*}{$\begin{array}{c}\text { Aspek yang } \\
\text { direspon }\end{array}$} & \multicolumn{2}{c}{ Respon Siswa } & \multicolumn{2}{c}{ Persentase (\%) } \\
\cline { 2 - 5 } & Ya & Tidak & Ya & Tidak \\
\hline 1 & 21 & 0 & 100 & 0 \\
2 & 19 & 2 & 90,48 & 9,52 \\
3 & 20 & 1 & 95,24 & 4,76 \\
4 & 18 & 3 & 85,71 & 14,29 \\
5 & 21 & 0 & 100 & 0 \\
6 & 20 & 1 & 95,24 & 4,76 \\
7 & 21 & 0 & 100 & 0 \\
8 & 21 & 0 & 100 & 0 \\
9 & 20 & 1 & 95,24 & 4,76 \\
10 & 20 & 1 & 95,24 & 4,76 \\
11 & 18 & 3 & 85,71 & 14,29 \\
12 & 16 & 5 & 76,19 & 23,81 \\
13 & 15 & 6 & 71,43 & 28,57 \\
14 & 19 & 2 & 90,48 & 9,52 \\
15 & 21 & 0 & 100 & 0 \\
\hline \multicolumn{5}{c}{ Rata-rata }
\end{tabular}

Persentase rata-rata siswa yang memberi respon positif terhadap penerapan model pembelajaran treffinger dengan pendekatan saintifik sebesar $92,06 \%$. Dimana persentase rata-rata siswa yang memberi respon positif lebih dari $80 \%$ siswa. Hal ini menunjukkan kriteria efektifitas pembelajaran untuk respon siswa terpenuhi.

Selanjutnya berdasarkan analisis kualitatif menunjukkan sebagian besar siswa merasa senang dengan pembelajaran yang diterapkan. Siswa lebih termotivasi untuk terlibat aktif dalam proses pembelajaran yang pada akhirnya mampu memahami pembelajaran dengan baik. Sedangkan siswa yang kurang senang dalam proses pembelajaran karena tidak mengerti dengan materi yang diajarkan guru. Didalam kelas siswa terganggu dengan suasana ribut dan adanya siswa lain yang mengganggu. Serta merasa tidak memiliki motivasi untuk terlibat aktif dalam pembelajaran dengan masih adanya keraguan dalam menyampaikan pendapat.

\section{KESIMPULAN}

Kesimpulan yang diperoleh dari penelitian ini yaitu model pembelajaran treffinger dengan pendekatan saintifik efektif diterapkan terhadap kemampuan berpikir tingkat tinggi siswa. Hal ini dapat dilihat dari hasil belajar matematika siswa setelah diajar menggunakan model pembelajaran treffinger dengan pendekatan saintifik terhadap kemampuan berpikir tingkat tinggi menunjukkan bahwa skor rata-rata 54,22 dari skor minimal 41. Sebanyak 100\% siswa mencapai ketuntasan individu, artinya ketuntasan hasil belajar secara klasikal tercapai. Dan nilai rata-rata gain ternormalisasi siswa sebesar 0,33 yang berada pada kategori sedang. Selain itu, skor rata-rata aktivitas siswa sebesar 3,67 atau berada pada kategori sangat baik. Serta rata-rata presentase siswa yang memberi respon positif terhadap penerapan model pembelajaran treffinger dengan pendekatan saintifik sebesar $92,06 \%$.

Penelitian lanjutan dapat dikembangkan karena masih ada beberapa hal menarik yang dapat diteliti. Penerapan model pembelajaran treffinger dengan pendelatan saintifik dapat diterapkan sebagai model pembelajaran untuk mengukur variabel lain selain kemampuan berpikir tingkat tinggi. Selain itu, dapat diterapkan pada materi pembelajaran lainnya sebagai penelitian lanjutan dalam penelitian ini. 


\section{DAFTAR PUSTAKA}

Alifiah, I. (2018). Kemampuan Creative And Critical Thinking melalui Model Pembelajaran Treffinger dengan Strategi Metakognitif untuk Materi Bangun Ruang Sisi Datar Kelas VIII SMPN 1 DAU Malang. Jurnal Pendidikan Matematika. 4(2). 76-85.

Asmi. (2015). Pengaruh Pendekatan Scientific terhadap Kemampuan Berpikir Kritis Siswa dalam Pembelajaran Matematika. Jurnal Penelitian Pendidikan Matematika. 3(1). 4558

Huda, M. (2013). Model-Model Pengajaran dan Pembelajaran. Yogyakarta: Pustaka Pelajar.

Hugo, T.K. (2017). Instrumen Tes untuk Mengukur Kemampuan Berpikir Tingkat Tinggi Siswa SMA. Universitas Tanjungpura Pontianak

Permendikbud. (2013). Paparan Mendikbud tentang Pengembangan Kurikulum 2013. Jakarta : Kemdikbud

Kemendikbud. (2017). Konsep dan Implementasi Kurikulum 2013. Jakarta : Kemdikbud.

Kreathwohl. (2002). A revision of Bloom's Taxonomy: an overview. Theory into Practice, 41 (4). 1-8.

Kurniati, D. (2016). Kemampuan Berpikir Tingkat Tinggi Siswa SMP di Kabupaten Jember dalam Menyelesaikan Soal Berstandar PISA. Jurnal Penelitian dan Evaluasi Pendidikan. 20(2). 142-155.

Munandar, S.C. U. (2009). Mengembangkan Bakat dan Kreativitas Anak Sekolah. Petunjuk Bagi Para Guru dan Orang Tua. Jakarta: PT Gramedia Widiasarana Indonesia.

Musfiqon, H.M. (2015). Pendekatan Pembelajaran Saintifik. Sidoarjo : Nizamia Learning Center

Sari, R.F. (2014). Penerapan Model Pembelajaran Treffinger pada Pembelajaran Matematika Dalam Mengembangkan Kemampuan Kreatif Matematika Siswa Kelas VIII SMPN 12 Padang. Universitas Bung Hatta.

Thomas, A. \& Thorne, G. (2009). How to Increase Higher Order Thinking. [online]. http://www.edl.org/article/how-to-increase-high-order-thinking//. Diakses pada tanggal 28 Januari 2019

Treffinger, D.J. 1980. A Preliminary Models of Creative Learning. Texas: Prufrock Press Inc

Wicasari, B. (2016). Analisis Kemampuan Berpikir Tingkat Tinggi Siswa dalam Menyelesaikan Permasalahan Matematika yang Berorientasi pada HOTS. Universitas Sanata Dharma.

Widiani, T. (2016). Penerapan Pendekatan Saintifik dan Pengaruhnya Terhadap Kemampuan Komunikasi Matematika dan Berpikir Kreatif Siswa. Jurnal Pendidikan dan Pembelajaran Khatulistiwa. 5(1). 1-12. 